\title{
PENGARUH AKTIVITAS PASAR DAN REPUTASI UNDERWRITER TERHADAP EXCESS RETURNS DALAM PROSES PENJAMINAN SAHAM IPO DI BURSA EFEK INDONESIA
}

\author{
Oleh: \\ Arni Utamaningsih*)
}

ABSTRAKSI

Penelitian ini mengklarifikasi peranan underwriter sebagdi partisipan aktif di dalam proses IPO dan mengilustrasikan bagaimana aktivitas-aktivitas penjaminan dikoordinasi oleh investment bank. Proses IPO merupakan serangkaian aktivitas-aktivitas yang terintegrasi, saling tergantung dan terbagi atas perioda premarket, issue-date dan aftermarket. Studi ini mencoba mentyajikn: analisis yang lebih komprehensif mengenai keterknitan antar perioda itu dan memandang proses IPO sebagai suatu keterkaitan yang utuh dan tidak lagi dipandang parsial sebagaimana telah dibahas pada studi-studi sebelumnya. Analisis dalam studi ini menunjukkan, bahwa reputasi underwriter mempunyai implikasi, baik terhadap aktivitas underwriter selama proses penjaminan saham IPO maupun terhadap investor returns.

Reputasi underwriter meriupakan determinan yang positif, tetapi berpengaruh lemah terhadap aktivitas underwriter pada perioda premarket, tidak berpengaruh terhadap aktivitas stabilisasi harga pada perioda aftermarket, dan tidak berpengaruh terhidap investor returns. Aktivitas-aktivitas underwriter pada perioda premarket merupakan determinan yang signifikan terhadap initial returns tetapi tidak berpengaruh terhadap aktivitas-aktivitas pada perioda aftermarket maupun returns jangka pendek. Initial returns secara signifikan berpengaruh terhadap aktivitas underwriter pada perioda aftermarket maupun terhadap returns jangka panjang. Hasil penelitian ini diperoleh melalui pengujian secara simultan, dengan mempertimbangan aktivitas-aktivitas pasar yang dilakukan underwriter serta atribut reputasi yang dimilikinya. Lebih jauh, path analysis dapat menggambarkan rangkaian aktivitas dan reputasi underwriter itu sebagai suatu proses IPO dan menjelaskan hubungannya dengan investor returns.

Kata kunci : Reputasi Underwriter, Aktivitas Underwriter, Partial Price Adjustment, Underpricing, Price Stabilization, Exces Returns, Path Analysis.

*) Arni Utamaningsih adalah Mahasiswa S3 Manajemen UGM 
Ketika sebuah perusahaan pertama kali go public, umumnya perusahaan penerbit saham (emiten) menggunakan jasa underwriter sebagai pihak ketiga yang turut menjembatani kepentingan emiten dan investor. Investment bank sebagai pihak underwritermenyediakan jasa penjaminan saham serta membantu emiten dalam proses emisi. Proses emisi saham-saham IPO terbagi atas tiga perioda, yaitu perioda premarket, pelaksanaan emisi saham di pasar perdana (issue date) dan aftermarket. Penelitian-penelitian terdahulu yang mengkaji saham-saham IPO memandang proses IPO sebagai seri yang terpisah-pisah. Hubungan antara seri premarket, issue date dan aftermarket tidak jelas, atau kaitan antara ketiga seri tersebut tidak terhubung. Sehingga pada gilirannya akan menghasilkan kesimpulan yang terisolasi dan parsial. Disisi lain, keterkaitan perioda premarket, issue-date dan aftermarket yang merupakan bagian krusial dalam proses penjaminan saham-saham IPO.

Penelitian ini bermaksud untuk mengkaitkan perioda premarket, issuedate dan aftermarket sèhingga menjadi suatu proses yang terdiri atas komponenkomponen emisi saham IPO yang saling berkaitan, utuh dan terintegrasi. Keterkaitan ini dipandang dengan cara menginvestigasi serangkaian aktivitas underwriter dengan atribut reputasinya pada perioda premarket, issue-date dan aftermarket. Jika dalam model IPO pricing yang dikembangkan oleh Rock (1986) dan Allen dan Faulhaber (1989), underwriter ditunjukkan sebagai partisipan pasif di dalam proses IPO, maka dalam penelitian ini underwriter bertindak sebagai partisipan aktif. Penelitian ini tidak hanya menggambarkan perusahaan penerbit saham dan investor saja, tetapi juga peran krusial underwriter di dalam proses strategic pricing, mengalokasikan saham serta menstabilisasi harga pasca IPO.

Seluruh aktivitas pasar yang diselenggarakan oleh underwriter tercermin dalam perubahan nilai partial price adjustment, underpricing, price stabilization dan abnormal returns yang merupakan fenomena-fenomena krusial yang terjadi pada perioda premarket, issue date dan aftermarket. Dengan demikian aktivitas underwriter dalam memasarkan saham IPO pada perioda premarket akan berpengaruh secara simultan terhadap aktivitas underwriter pada perioda issue date, selanjutnya aktivitas pada perioda premarket dan issue date itu akan berpengaruh secara simultan pula terhadap perioda aftermarket. Reputasi underwriter diduga turut mempengaruhi opini pemodal mengenai kualitas perusahaan emiten dan berkaitan dengan prospek jangka panjangnya. Oleh karenanya, penelitian ini juga menginvestigasi hubungan antara reputasi underwriter dan aktivitas pasar (market activities) serta hubungan keduanya terhadap short run dan long run investor returns.

Pada perioda premarket terdapat fenomena partial price adjustment (PPA) yang diduga terkait dengan persentase kisaran harga penawaran (percent of preliminary offer price range) yang disajikan dalam preliminary prospectus (Hanley, 1993). Penelitian Logue et al., (2002) menggunakan expected proceeds (EXPRO), preliminary offer price range (\%PRIRNG) dan log of revenue (REV) sebagai faktor eksogenus yang diduga berpengaruh terhadap partial price 
Arni Utamaningsih: Pengaruh Aktivitas Pasar dan Reputasi Underwriter ...

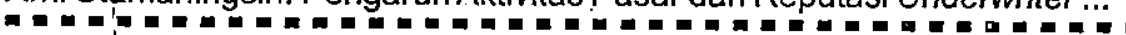

adjustment (PPA). Ketiga faktor eksogenus tersebut diindikasi sebagai faktor spesifik yang mempengaruhi proses penjaminan saham-saham IPO dan return bagi investor (Logue, 1973; Logue dan Lindvall, 1974).

Pada perioda issue-date, yaitu saat saham diperdagangkan di pasar perdana, terdapat fenomena underpricing. Fenomena underpricing merupakan fenomena yang paling krusial tërkait dengan penetapan harga perdana, mengapa harga itu sepertinya dipatok pada level harga yang "mengundang" permintaan yang berlebihan dari calon investor. Mengapa penetapan harga saham IPO selalu lebih rendah dari harga yang sesuai dengan penilaian pasar, hingga kini tidak diketahui dengan pasti apa yang menjadi penyebab utamanya. Sebagian besar teori akademik menyatakan bahwa underpricing dilakukan secara sengaja (Baron, 1982; Rock, 1986; Tinic, 1988; Allen dan Foulhaber, 1989; Grinblatt dan Hwang, 1989; Welch, 1989). Beberapa peneliti menyatakan bahwa underpricing disebabkan adanya asymmetric information (Baron, 1982; Rock 1986; Beatty dan Ritter, 1986). Rock (1986) berargumentasi bahwa uninformed investor mencerminkan a winner's curse. Baron (1982) menyatakan adanya asymmetric information antara underwriter dengan perusahaan emiten. Sementara itu jika underwritermemberikan jaminan full commitment, maka semua sekuritas dijamin harus terjual semua. Kalau tidak terjual, underwriter itulah yang akan membeli sisanya. Karena underwriter menanggung risiko harus membeli sekuritas yang tidak terjual, mereka cenderung berupaya untuk bernegosiasi dengan calon emiten supaya sekuritas yang ditawarkan tidak terlalu mahal harganya (Husnan, 2001).

Pada perioda aftermarket, terdapat fenomena price stabilization. Dalam proses penjaminan IPO, fenomena priçe stabilization diduga|terkait dengan underpricing. Dalam jangka setelah 30 hari sejak hari pertama perdagangan di pasar sekunder, diduga intensitas price stabilization semakin menurun. Penelitian ini menggunakan path analysis untuk mengidentifikasi secara jelas antara aktivitas pasar dan reputasi underwriter. Dengan mengindikasi perbedaan itu, diharapkan hasil penelitian ini dapat menggambarkan dan menarik kesimpulan yang lebih baik mengenai proses penjaminan saham IP.O dan pengaruhnya terhadap investor returns pada tiga horison waktu yang berbeda setelah IPO (1 bulan, 3 bulan, dan 6 bulan).

Penelitian ini juga mengacu pada peraturan Bapepam No. IX.A.2 Baru; mengenai jadwal penawaran umum. Pada peraturan baru ini terdapat perioda red hering, yaitu perioda bookbuilding yang memungkinkan diselenggarakannya strategic pricing.

\section{B. LANDASAN TEORI DAN PENGEMBANGAN HIPOTESIS}

Gambar 1 berikut ini, merupakan rerangka berpikir dan model konseptual pengembangan hipotesis. 


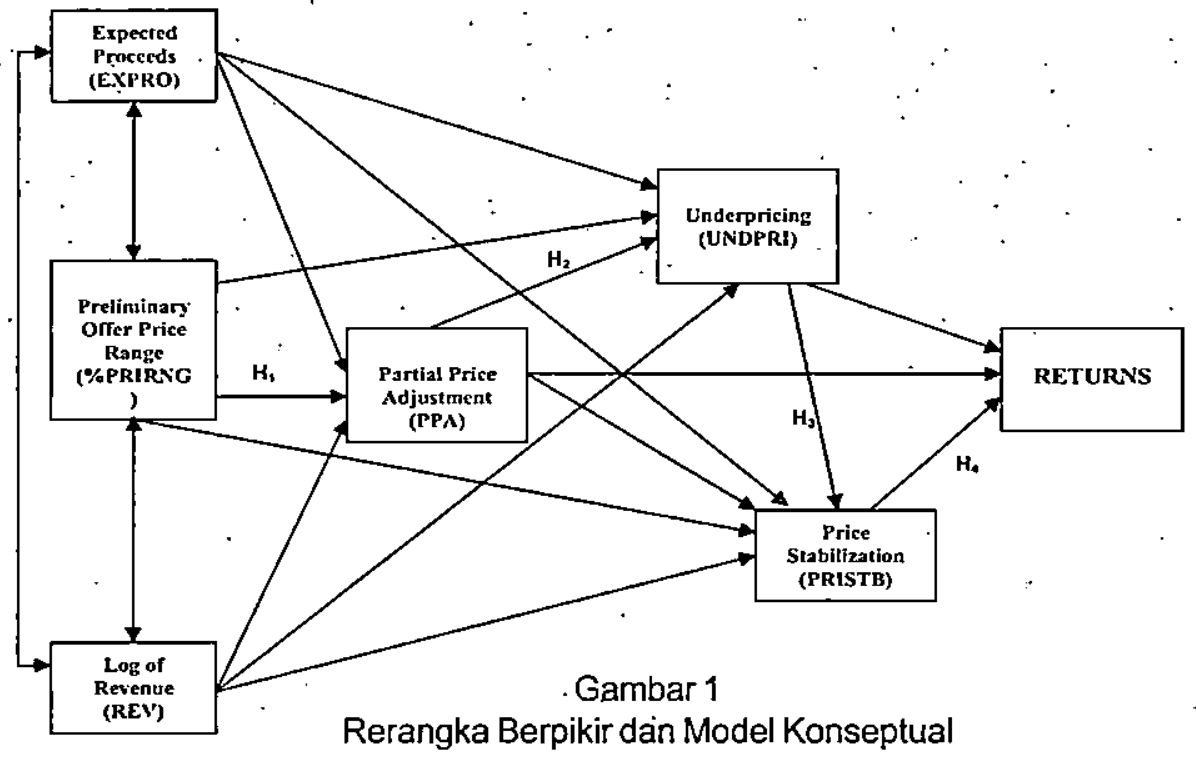

\section{Partial Price Adjustment (PPA)}

Preliminary offer price range merupakan determinan yang diduga mempengaruhi aktivitas underwriter dan return investor. Ekspektasi investor terhadap pemberian harga saham baru berkaitan dengan ex ante uncertainty mengenai nilai perusahaan emiten (Beatty dan Ritter, 1986). Seiring dengan meningkatnya uncertainty, kos yang digunakan calon investor untuk mengumpulkan dan menganalisis informasi mungkin akan menjadi lebih tinggi.

Selama perioda pendaftaran (filing period), sangat mungkin terjadi perubahan harga penawaran, yaitu pada saat-saat sebelum tanggal penerbitan saham di pasar perdana. Benveniste dan Spindt (1989) berargumentasi bahwa melalui perubahan harga penawaran, underwriter dapat menghimpun informasi untuk menaksir kekuatan permintaan investor yang prospektif. Jika terdapat permintaan yang kuat, underwriterakan mematok harga penawaran yang tinggi. Jika investor potensial mengetahui harga yang tinggi tersebut dan bersedia membayarnya, maka undenwriter akan menawarkan return yang lebih menarik.

- Fakta yang mendukung argumen di atas dikemukakan oleh Hanley (1993). Hanley (1993) mendokumentasikan perubahan harga penawaran selama perioda pendaftaran, dan menemukan bahwa underwritertidak sepenuhnya melakukan penyesuaian harga penawaran saham mereka ke level yang lebih tinggi untuk menjaga underpricing tetap konstan ketika permintaan menguat. Jadi ketika underwriter merevisi harga saham menjadi lebih tinggi dari estimasi harga penawaran yang original, yang dimuat dalam prospektus pendahuluan, maka underpricing cenderung lebih tinggi. Bradley dan Jordan (2002) menunjukkan, bahwa amandemen harga penawaran mempunyai kekuatan prediksi yang signifikan untuk memperkirakan underpricing. Saham-saham dengan harga penawaran di atas file range pada umumnya lebih underpriced. Hasil penelitian Logue et al. (2002) juga menyatakan hal yang sama, yaitu preliminary offer. 
Arni Utamaningsih: Pengaruh Aktivitas Pasar dan Reputasi Undenwriter ...

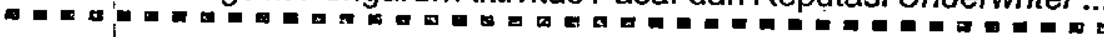

price range merupakan determinan positif bagi partial price adjustment. Berdasarkari rangkaian penjelasan di atas, maka disusun hpotesis sebagai berikut:

H1: · Preliminary offer price berpengaruh positif terhadap partial price adjustment.

\section{Underpricing (UNDPRI)}

Walaupun underwriter sudah berusaha menstabilkan preliminary price maupun offer size, berapa final offer price dari jumlah saham yang sesungguhnya dijual tidak dapat dipastikan sampai pada hari penerbitan saham. Laughran \& Ritter (2002) menggunakan prospect theory untuk menjelaskan mengapa emiten setuju untuk menetapkan harga saham IPO pada level yang "mengundang" excess demand. Partial price adjustment yang terjadi karena permintaan penawaran yang tinggi menghasilkan tingkat kesejahteraan yang lebih baik bagi emiten dan secara simultan memberikan excess profit bagi investor.

Logue et al. (2002) berpendapat bahwa aktivitas premarket underwriter merupakan faktor yang berpengaruh paling signifikan terhadap terjadinya underpricing. Keputusan underwriter dalam menetapkan harga penawaran dan pengalokasian saham mengundang respon investor yang tercermin dalam rationing equilibrium. Perubahan harga yang terjadi merupakan bukti keterampilan underwriter dalam memasarkan saham-saham IPO. Logue et al. menemukan investment banks yang berkualitas tinggi lebih mungkin untuk menyesuaikan harga ke atas selama proses IPO. Hasil ini membuktikan bahwa underwriter reputation memfasilitasi pengadaan aktivitas premarket underwniter. Rationing dan underpricing merupakan konsekuensi dari penyesuaian harga yang terakhir terjadi.

Menurut pendapat Benveniste dan Spindt (1989); Benveniște, Busaba dan Wilhelm (1996), investor harus diberikan kompensasi atas informasi privat yang mereka miliki. Informasi privat itu terkait dengan nilai perusahaan emiten yang sesungguhnya. Melalui kombinasi antara underpricing dan rationing, reward. atas informasi semacam itu dapat didistribusikan secara selektif kepada para investor yang memiliki informasi. Hasil penelitian yang mendukung temuan Benveniste dan Spindt (1989) adalah penelitian Bradley dan Jordan (2002), yang menunjukkan 35\%-50\% variasi IPO mengalami underpricing. Underpricing dapat dipredikși melalui public information yang diperoleh sebelum tanggal penerbitan saham. Fenomena partial price adjustment menyediakan informasi publik yang lebih luas, walaupun tidak sepenuhnya merefleksikan semua tipe informasi publik. Berdasarkan rangkaian penjelasan tersebut, maka disusun hipotesis sebagai.berikut:

H2: Partial price adjustment berpengaruh positif terhadap underpricing.

\section{Price Stabilization (PRISTB)}

Aktivitas price stabilization atau.stabilisasi harga yang dilakukan underwriter ke dalam transaksi perdagangan saham ditujukan untuk mencegah atau memperlambat penurunan harga pasar. Price support atau stabilisasi harga melibatkan modal yang besar, sehingga dalam prakteknya yang terlibat adalah 
investment banker yang bermodal besar pula. Menurut Hanley et al. (1993), price stabilization dalam proses IPO merupakan aktivitas perioda aftermarket yang terjadi di pasar sekunder. Hasil penelitian Hanley et al. menemukan spread yang lebar antara harga pasar tutupan dengan harga penawaran, setelah itu terjadi stabilisasi harga. Pada perioda berikutnya mereka mendokumentasi terjadinya returm negatif yang signifikan. Berdasarkan kecenderungan tersebut, maka dapat disimpulkan bahwa aktivitas stabilisasi harga tidak terus berlanjut. Stabilisasi harga merupakan bagian dari strategi marketing yang dilakukan underwriter dalam memasarkan saham-saham IPO.

Menurut Benveniste et al. (1996), kualitas investment bank merupakan proksi yang baik untuk mengukur kredibilitas aktivitas aftermarket underwriter. Komitmen yang kredibel sangat penting untuk menunjang aktivitas price stabilization pada perioda aftermarket. Logue et al. (2002) menggunakan ranking kualitas Carter dan Manaster (1990) untuk mengukur kualitas underwriter terkait dengan kemampuannya dalam menstabilisasi harga. Hasil penelitian menunjukkan kualitas ranking underwriter berhubungan secara signifikan dengan aktivitas stabilisasi harga.

Ellis, Michaely dan O'Hara (2000) menguji aftermarket trading. Ellis et al. menemukan fakta bahwa lead underwriterselalu dominan sebagai market maker dan memegang posisi yang substansial dalam perdagangan aftermarket. Lead underwriter melakukan aktivitas stabilisasi bagi perdagangan saham-saham IPO yang kurang sukses. Aftermàrket trading menciptakan keuntungan yang positif tergantung pada derajat underpricing. Berdasarkan rangkaian penjelasan di atas maka disusun hipotesis berikut ini:

H3: Underpricing berpengaruh positif terhadap price stabilization.

\section{Abnormal Returns (RETURNS)}

Anggarwal (2000) berpendapat aktivitas aftermarket underwriter kurang transparan. Intervensi undenwiterterhadap harga saham tidak sepenuhnya dapat dipahami, karena tidak tersedianya data dan praktek di industri yang kurang transparan. Hasil penelitiannya menjelaskan aktivitas aftermarket underwriter dilakukan dengan cara menstimulasi demand melalui short covering dan memperketat penawaran untuk menghindari dan mengendalikan flipping atas saham. Price stabilization ini berdampak pada berkurangnya fee underwriter. Underwriter mengelola aktivitas price support dengan menggunakan kombinasi aftermarket short covering, penalty bids, dan secara selektif menggunakan overallotment option.

Fishe (2002) menemukan fakta bahwa price stabilization meningkat pada perdagangan saham IPO yang lemah dan terdapat hubungan yang positif antara elastisitas permintaan dengan returns IPO. Logue et al. (2002) mengatakan bahwa aktivitas underwriter pada perioda aftermarket mempunyai hubungan yang kuat dengan long-run investor returns. Aktivitas price stabilization penting pengaruhnya terhadap return yang diperoleh unvestor, terutama pada bulan ke3,6 dan 12:Berdasarkan rangkaian penjelasan di atas, maka disusun hipotesis sebagai berikut:

H4: Price stabilization berpengaruh positif terhadap abnormal returns. 
Penelitian menggunakan data sekunder berupa: harga penawaran perdana, jumlah saham yang dijual, kisaran harga penawaran, pendapatan, harga penutupan pada hari pertamia perdagangan, harga penutupan pada 30 hari pertama perdagangan, indeks harga saham gabungan (IHSG) dan peringkat reputasi underwriter di Indonesia, khususnya di Bursa Efek Indonesia. Perioda pengamatan dilakukan terhadap perusahaan-perusahaan yang melakukan IPO di Indonesia sejak bulan Januari 2001 sampai dengan Desember 2002. Retum saham diamati sejak bulan pertama, ketiga dan keenam sejak saham diterbitkan pertama kali, sehingga penelitian ini menggunakan jangka waktu pengamatan 6 (enam) bulan ke depan untuk menganalisa kinerja perusahaan. Perolehan sampel penelitian ini terbatas, hanya 53 sampel, karena sampel harus memenuhi kriteria spesifik yaitu saham-saham IPO yang prosedur pelaksanaannya sesuai dengan jadwal penawaran umum menurut Bapepam No. IX.A.2

\section{Pengukuran dan Operasionalisasi Variabel}

1. Variabel Expected Proceeds (EXPRO)

EXPRO $=\mathrm{N} \times \mathrm{P}_{\mathrm{a}}$

Notasi: $\quad \mathrm{N}=$ offer size (jumlah saham yang dijual)

$\mathrm{P}_{\mathrm{a}}=$ harga penawaran perdana

2. Preliminary Offer Price Range (\%PRIRNG)

$\%$ PRIRNG $=\frac{P_{1}-P_{0}}{P_{0}} \times 100 \%$

Notasi: $P_{1}=$ harga penawaran tertinggi pada perioda premarket

$P_{0}=$ harga penawaran terendah pada perioda premarket

3. Log of Revenue (REV)

REV merupakan variabel kontrol, yaitu logaritma natural dari revenue yang diperoleh perusahaan emiten dalam tahun fiskal yang diterbitkan terakhir sebelum dilakukan IPO.

4. Partial Price Adjustment (PPA)

Aktivitas partial price adjustment (PPA) dalam penelitian in dikuantifikasi dengan cara mengukur revisi expected offer prices selama perioda premarket terlebih dahulu. Rumus perhitungannya adalah sebagai berikut:

$P_{e}=\frac{P_{1}+P_{0}}{2} \quad P P A=\frac{P_{a}+P_{e}}{P_{e}}$

Notasi: $P_{a}=$ harga penawaran perdana

$P_{e}=$ harga penawaran yang diharapkan 
5. Underpricing(UNDPRI)

$U N D P R I=\frac{P_{m}-P_{a}}{P_{a}}$

Notasi: $\quad P_{m}=$ harga penutupan pada hari pertama perdagangan

$P_{a}=$ harga penawaran perdana

6. $\quad$ Price Stabilization (PRISTB)

Agar dapat memperoleh gambaran aktivitasnya maka penelitian ini menggunakan proksi, yaitu melalui cara mencermati jarak (magnitude) dan durasi stabilisasi harga yang kemudian dapat diambil kesimpulan. Kesimpulan ini merupakan hasil observasi harga sejak tanggal pertama di pasar sekunder, dimana harga jatuh dibawah harga penawaran perdana: Selanjutnya pola itu dibuat discrete categorical variable berdasarkan konvensi jumlah hari seperti berikut ini:

Value 1: Harga pasar turun dibawah harga penawaran perdana dalam 2 hari sejak tanggal penawaran (Market prices<issue price). Diindikasikan underwriter melakukan aktivitas dukungan yang lebih cepat dalam menstabilkan harga.

Value 2 : Harga pasar turun turun dibawah harga penawaran perdana dalam 28 hari, dengan asumsi underwriter memperpanjang partisipasinya dalam aktivitas stabilisasi harga.

Value 3 : Jika tidak pernah terjadi penurunan harga dibawah harga penawaran perdana dalam tempo 30 hari pertama perdagangan (Market prices>issue price). Dalam kondisi ini underwriter dipandang tidak perlu melakukan aktivitas stabilitas harga.

4. Abnormal Returns

Hasil perhitungan abnormal retum dapat diperoleh dengan menggunakan return pasar (market adjusted model). Kinerja saham pada perioda aftermarket dilakukan melalui pendokumentasian abnormal retum saham pada akhir bulan ke-1, ke-3 dan ke-6.

a. Retum saham (pasar) pada perioda bulan ke-1, ke-3 dan ke-6 dihitung dengan rumus:

$$
R_{i(m) t}=\frac{P_{i(m) t}-P_{i(m) t-1}}{P_{i(m) t-1}}
$$

dimana: $R_{i t}$ = return saham i (pasar) pada periodat

$P_{i f}$ = harga saham i (IHSG) pada perioda t

$p_{i t-1}=$ harga saham $\mathrm{i}(\mathrm{IHSG})$ pada perioda $\mathrm{t}-1$ 
Berdasarkan evaluasi normalitas data, outliers, multicollineanity dan goodness of fit index, seluruh model path analysis yang dikembangkan dinyatakan representatif. Tabel 1 memuat seluruh hasil pengujian model untuk memprediksi besaran excess returns pada jangka pendek ( 1 bulan) dan jangka yang lebih panjang ( 3 dan 6 bulan). 
Tabel 1

Hasil Uji Hipotesis untuk Model 1a, 1b dan 1c

\begin{tabular}{|c|c|c|c|c|}
\hline Pengaruh Antar Vāïiabel & $\begin{array}{c}\text { Arah } \\
\text { Pengaruh }\end{array}$ & $\begin{array}{c}\text { Standardized } \\
\text { Estimate }\end{array}$ & c.r. & Keterangan \\
\hline $\mathrm{PPA} \leftarrow$ EXPRO & + & 0.402 & $2.917^{\star \star}$ & Signifikan \\
\hline $\mathrm{PPA} \leftarrow \mathrm{REV}$ & - & -0.057 & -0.415 & Tidak signifikan \\
\hline PPA $\leftarrow$ PRIRNG & + & $0.50 \mathrm{I}$ & $4.748 * \hbar$ & Signifikan $\left(\mathrm{H}_{\mathrm{i}}\right)$ \\
\hline UNDPRI $\leftarrow$ EXPRO & - & -0.088 & -0.518 & Tidak signifikan \\
\hline UNDPRI $\leftarrow$ PPA & $=$ & -0.506 & $-3.183^{\star *}$ & Signifikan $\left(\mathrm{H}_{2}\right)$ \\
\hline UNDPRI $\leftarrow$ PRIRNG & + & 0.147 & 1.016 & Tidak signifikan \\
\hline UNDPRI $\leftarrow$ REV & - & -0.021 & -0.131 & Tidak signifikan \\
\hline PRISTB $\leftarrow$ EXPRO & - & -0.246 & $-1: 441$ & Tidak signifikan \\
\hline PRISTB $\leftarrow$ PPA & + & 0.112 & 0.646 & Tidak signifikan \\
\hline PRISTB $\leftarrow$ UNDPRI & \pm & 0.447 & $3.240^{t *}$ & Signifikan $\left(\mathrm{H}_{3}\right)$ \\
\hline PRISTB $\leftarrow$ REV & + & 0.179 & 1.135 & Tidak signifikan \\
\hline PRISTB $\leftarrow$ PRIRNG & - & -0.159 & -1.087 & Tidak signifikan \\
\hline RETURNl $\leftarrow$ PPA & - & -0.206 & -1.354 & Tidak signifikan \\
\hline RETURN1 $\leftarrow$ UNDPRI & - & -0.189 & -1.138 & Tidak signifikan \\
\hline RETURN1 $\leftarrow$ PRISTB & \pm & 0.179 & 1.184 & Tidak signifikan(HA) \\
\hline RETURN3 $\leftarrow$ PPA & - & -0.444 & -0.738 & Tidak signifikan \\
\hline RETURN3 $\leftarrow$ UNDPRI & - & -0.355 & $-2.171^{\star}$ & Signifikan \\
\hline RETURN3 $\leftarrow$ PRISTB & + & 0.219 & 1.472 & Tidak signifikan \\
\hline RETURN6 ↔ PPA & - & -0.221 & $-1.581^{\star}$ & Marginal \\
\hline RETURN6 $\leftarrow$ UNDPRI & - & -0.550 & $-3.610 * *$ & Signifikan \\
\hline RETURN6 $\leftarrow$ PRISTB & + & 0.088 & 0.636 & Tidak signifikan \\
\hline
\end{tabular}

Keterangan: $\quad$ Signifikan pada $\alpha 10 \%, \mathrm{df}=3$, one tailed test.

** Signifikan pada $\alpha 5 \%, \mathrm{df}=3$, one tailed test.

Pengujian hipotesis pertama terbukti, data pengamatan sesuai dengan garis teoritis (prediksi menurut model). Variabel preliminary offer price range (PRIRNG) merupakan determinan yang berpengaruh langsung, positif dan signifikan pada level 0.050 terhadap variabel partial price adjustment (PPA). Disamping itu, expected proceeds (EXPRO) juga berpengaruh sama dengan PRIRNG terhadap PPA. Temuan ini mengindikasikan bahwa undenwriter pada umumnya underestimate akan permintaan investor terhadap saham-saham yang berisiko. Nampaknya harga penawaran semakin dikurangi seiring dengan kenaikan risiko saham tidak terjual. Logue et al (2002) mengatakan bahwa price adjustment yang terjadi selama perioda premarket ditujukan untuk mengkompensasi investor dalam bentuk additional discount (terkait dengan jumlah saham yang ditawarkan) dan memberikan premium (terkait dengan uncertainty). Penelitian ini menunjukkan bahwa partial price adjustment cenderung mengarahkan harga penawaran perdana lebih rendah dari nilai saham sebenarnya. Besarnya selisih harga yang terjadi disebut sebagai premium. Mekanisme ini menjelaskan bagaimana proses terciptanya harga perdana, terkait dengan uncertainty riskyang ditanggung calon investor. Sedangkan bagaimana mekanisme terciptanya harga penawaran perdana melalui gambaran additional discount tidak dapat dijelaskan dengan baik, karena data yang memuat prosentase perubahan jumlah saham yang ditawarkan saat bookbuliding tidak tersedia. 
Arni. btamaningsih: Pengaruh Aktivitas Pasar dan Reputasi Underwriter...

ज a

Pengujian hipotesis kedua didukung oleh data secara signifikan ciengan arah yang bertolak belakang. Berarti PPA mempengaruhi underpricing (UNDPRI) secara langsung dan negatif. Semakin partial price adjustment bergesar ke arah bawah kisaran harga penawaran awal, maka saham semakin mengalami underpricing. Fenomena underpricing atas saham-saham IPO di indonesia justru dijelaskan oleh peristiwa pergeseran harga penawaran perdana di bawah kisaran harga penawaran awal (PRIRNG). Dengan menggeser harga di bawah PRIRNG, maka risiko saham tidak terjual semakin kecil. Dengan pertimbangan underwriter memiliki informasi yang lebih baik tentang pasar modal dibanding perusahaan emiten, ditambah lagi informasi pada saat "road show' pada perioda bookbulding, maka undenwritermemanfaatkan informasi yang dimilikinya untuk membuat kesepakatan harga IPO yang optimal.

Fenomena Underpricing dapat diinterpretasikan sebagai suatu fakta untuk "mengundang" investor agar melakukan bidding secara lebih|agresif. Underpricing yang terjadi atas saham-saham IPO di Indonesia pada perioda tahun 2001-2002 justru terjadi pada perusahaan-perusahaan yang mempunyai ratarata dasar revenue lebih kecil. Sejalan dengan argumentasi Brennan dan Franks (1997) bahwa underpricing menjamin terjadinya oversubcription sehingga memungkinkan penerbit saham dapat melakukan penjatahan k'epemilikan post IPO secara strategik melalui proses pengalokasian saham. Dengan demikian underpricing dan rationing merupakan dua hal yang serangkaian sehingga memungkinkan bagi orang dalam perusahaan (insiders) untuk tetap menguasai pengendalian perusahaan pasca IPO.

Pengujian hipotesis ketiga didukung oleh data secara positif dan signifikan. $\mathrm{H}_{3}$ terbukti, semakin tinggi derajat underpricing maka semakin berkurang intensitas price stabilization. Hasil ini konsisten dengan penemuan Logue et al. (2002) dan Benveniste et al. (1996). Benveniste et al. memprediksi bahwa underpricing dan price stabilization merupakan dua aktivitas yang saling substitusi. Undenwritermemberi harga secara lebih akurat untuk saham-saham yang permintaannya rendah. Revisi harga penawaran di bawah kisaran harga mungkin cukup akurat untuk memoderasi kekuatan hubungan antara aktivitas underwriter pada perioda premarket dan aftermarket.

Pengujian hipotesis keempat kurang didukung oleh data, arah hubungannya positif. Dengan demikian $\mathrm{H}_{4}$ kurang terbukti. Dengan kata lain tidak ada bukti yang mendukung bahwa aktivitas yang dilakukan undenwriter pada perioda premarket dan aftermarket dapat mempengaruhi harga di pasar sekunder. Hasil penelitian pada domain ini kurang dapat menjelaskan apakah stabilisasi harga dengan berbagai intensitasnya dapat menentukan abnormal retums pada bulan pertama pasca IPO. Demikian pula abnormal returns tidak dapat dijelaskan melalui partial price adjustment maupun underpricing. Walaupun kurang signifikan, arah pengaruh price stabilization terhadap abnormal retums yang positif mengindikasikan bahwa underwriter sudah melakukan stabilisasi harga, tetapi pengaruhnya kurang terasa, karena tingkat penurunan harga yang kuat (flipping). Tindakan stabilisasi harga tidak mampu membendung harga yang terus turun, sehingga performance saham semakin buruk. 
Selanjutnya hasil pengujian sehubungan dengan peran reputasi underwriter dengan menggunakan proxy Carter-Manaster quality ranking, dilaporkan sebagaimana tabel 2 berikut ini:

Tabel 2

Hasil Uji Hipotesis untuk Model 2a, 2b dan 2c

\begin{tabular}{|c|c|c|c|c|}
\hline \multirow{2}{*}{ 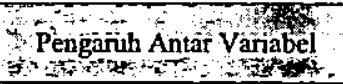 } & Arah & Standardized & \multirow{2}{*}{ 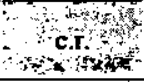 } & \multirow{2}{*}{${ }_{\text {W }}$ Keterangan } \\
\hline & Pengaruh: & W-Estimate & & \\
\hline $\mathrm{PPA}_{4} \mathrm{PRIRNG}$ G & $\therefore+\cdots$ & 0.502 & $4813^{*}$ & Signifikan $\left(\mathrm{H}_{1}\right)$ \\
\hline PPA $\leftarrow$ EXPRO & + & 0.384 & $2.802^{\star \star \hbar}$ & Signifikan \\
\hline PPA $\leftarrow$ REV & - & -0.093 & -0.669 & nifikan \\
\hline PPA: $\quad \hat{R A N K}$ & \pm & $0.130^{\circ}$ & $1514^{*}$ & Marginal $\mathrm{x}$ \\
\hline UNDPRI $\leftarrow$ PRIRNG & + & & 0.967 & Tidak signifikan \\
\hline UNDPRI $\leftarrow$ EXPRO & - & & -0.494 & Tidak signifikan \\
\hline UNDPRI $-\mathrm{PPA}^{2}$ & - & $-0.493^{\circ}$ & $-3.069 * *$ & Signifikan $\left(\mathrm{H}_{2}\right)$ \\
\hline UNDPRI $\leftarrow$ REV & - & & -0.006 & nifikan \\
\hline UNDPRI $\leftarrow$ 'RANK & $\because$ & & $=0.516$ & nifikañ \\
\hline PRISTB $\leftarrow$ EXPRO & - & & -1.418 & nifikan \\
\hline$\leftarrow$ PRIRNG & - & & -1.139 & nifikan \\
\hline PRISTB $\leftarrow$ PPA & + & & 0.718 & nifikan \\
\hline PRISTB - UNDPRI & + & & $3.199 \pm$ & Signifikan $\left(\mathrm{H}_{3}\right)$ \\
\hline PRISTB $\leftarrow$ REV & + & & 1.256 & ifikan \\
\hline PRISTB $\leftarrow$ RANK & $=$ & & -0.633 & nifikan \\
\hline RETURN1 $\leftarrow$ PPA & - & & -1.281 & iifikan \\
\hline RETURN1 - UNDPRI & - & & -1.165 & ifikan \\
\hline RETURN $1-$ PRISTB &.+ & 0.176 & 1.161 & fikan $\left(\mathrm{H}_{4}\right)$ \\
\hline RETURN1 $\leftrightarrows \mathrm{RANK}$ & $\because$ & $5]^{+}$ & 0.370 & nifikan \\
\hline RETURN3 4 PPA & - & & -0.5 & nifikan \\
\hline RETURN3 $\leftarrow$ UNDPRI & - & & $-2.335^{\star \star}$ & ikan \\
\hline RETURN3 $\leftarrow$ PRISTB & + & & 1.40 & ignifikan \\
\hline RETURN $3=$ RANK & 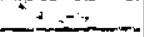 & -0.207 & $-1.543^{t}$ & Marginal \\
\hline RETURN6 $\leftarrow$ PPA. & - & -0.219 & $-1.546^{\star}$ & Marginal \\
\hline RETURN6 $\leftarrow$ UNDPRI & $-\cdot$ & & $-3.607^{* *}$ & Signifikan \\
\hline RETURN6 $\leftarrow$ PRISTB & \pm & & 0.629 & Tidak signifikan \\
\hline RETURNG $\leftarrow$ RANK & $\Xi$ & -0.012 & $=0.095$ & Tidak signifikan \\
\hline
\end{tabular}

Keterangan: * Signifikan pada a $10 \%$, df $=3$, one tailed test.

** Signifikan pada $\alpha 5 \%, \mathrm{df}=3$, one tailed test.

Pengujian peran reputasi underwriter dengan menggunakan proxy CarterManaster quality ranking berpengaruh positif tetapi tidak signifikan terhadap partial price adjustment. Hasil penelitian kurang mampu menjelaskan bahwa kualitas underwriter yang rendah mempunyai masalah kredibilitas. Oleh karenanya hasil ini kurang mampu mendukung argumen bahwa underwriter yang bereputasi rendah kurang mampu meningkatkan harga penawaran perdana di atas kisaran penawaran harga awal. Koefisien reputasi underwriter juga tidak menunjukkan hasil yang signifikan dalam menjelaskan pengaruhnya terhadap initial retums (underpricing). Hasil pengujian peran reputasi undenwriter terhadap stabilisasi harga maupun abnomal returns menunjukkan pengaruh yang kurang 
Arni Utamaningsih:Pengaruh Aktivitas Pasar dan Reputasi Underwriter...

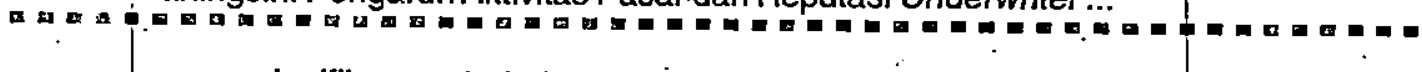

signifikan pada bulan pertama. Sehingga secara keseluruhan, model tidak terpengaruh oleh Carter-Manaster quality ranking. Masing-masing variabel eksogenus maupun endogenus sebagai variabel penjelas tetap konsisten dengan hasil pengujian sebelumnya, perubahan koefisien determinasi yang terjadi tidak cukup substansial. Pengaruh-pengaruh yang terjadi pada perioda premarket, issue date dan perioda aftermarket lebih dipengaruhi oleh aktivitas underwriter, sedangkan reputasi underwiter tidak memberikan pengaruh yang signifikan. Reputasi underwriter ataupun aktivitas undenwriter tidak berpengaruh terhadap abnormal returns pada bulan pertama. Dalam jangka lebih parjang, underpricing semakin signifikan menunjukkan pengaruhnya terhadap abnormal returns pada bulan ketiga dan meningkat pada bulan keenam ( -0.374 pada bulan ketiga menjadi -0.551 pada bulan keenam).

Performance jangka panjang saham-saham IPO di Indonesia lebih buruk dari pada return pasar (underperformance). Hasil pengujian ini kónsisten dengan temuan Ritter (1991), Brav dan Gompers (1997), Carter et al. (1998), Hanafi (2002) maupun Logue et al. (2002). Setelah jangka waktu 3 bulan, sahamsaham IPO di Indonesia sudah menampakkan underperformance dan trend. penurunan returns terus berlanjut sampai pengamatan 6 bulan berikutnya. $\mathrm{Di}$ negara lain aftermarket performance pada umumnya menunjukkan trend yang menurun setelah jangka waktu dua belas bulan. Sehingga dapat disimpulkan bahwa proses kinerja saham menjadi underperformance untuk saham-saham IPO di Indonesia jauh lebih cepat dibanding kasus serupa di negara-negara lain.

\section{F. PENUTUP}

\section{Keterbatasan Penelitian}

1. Jumlah sampel yang digunakan dalam penelitian ini terbatas, hanya 53 sampel. Setidaknya untuk pengujian yang demikian kompleks, jumlah sampelnya sekitar 125 unit.

2. Perioda amatan aftermarket terbatas, sehingga performance saham yang berhasil didokumentasi hanya sampai pada perioda 6 bulan setelah IPO. Perioda amatan yang lebih panjang, sepertinya akan dapat menjelaskan kinerja saham IPO lebih baik.

3. Returns pasar yang digunakan adalah IHSG, bukan indeks khusus yang sesuai dengan jenis portofolio masing-masing saham IPO. Hal ini disebabkan tidak tersedianya data indeks masing-masing industri selama perioda penelitian.

\section{Implikasi Penelitian}

1. Studi empirik diseputar peristiwa IPO yang lalu lebih menyorot aktivitasaktivitas undenwriterpada perioda yang terbatas selama proses penjaminan. Studi ini menyajikan analisa yang lebih komprehensif, yaitu rangkaian àktivitas penuh yang diselenggarakan underwriterpada perioda premarket, issue date dan aftermaket. 
2. Reputasi underwriter dan aktivitas pasar yang dilakukannya merupakan elemen-elemen dalam sebuah sequential, merupakan proses yang terintegrasi yang didedikasikan oleh underwriter untuk kepentingan perusahaan penerbit saham. Oleh karenanya, kesimpulan yang lebih baik mengenai proses penjaminan IPO dapat digambarkan jika pola hubungan ini merupakan hubungan yang penuh, bukan hubungan yang parsial.

3. Pada prinsipnya pengaruh reputasi underwriter terhadap investor return adalah pengaruh tidak langsung, melalui tindakan mereka pada perioda premarket underwriting. Ada kecenderungan reputasi underwriter memfasilitasi tindakan aktivitas premarket underwriting, sehingga ada baiknya perusahaan emiten mempertimbangkan penggunaan jasa underwriteryang bereputasi tinggi. Underwriteryang bereputasi tinggi memungkinkan proses aktivitas penjaminan saham lebih efisien.

4. Penelitian ini menguji prediksi menurut model, apakah data pengamatan sesuai dengan garis teoritis. Path analysis digunakan bukan untuk menghasilkan kausalitas, tetapi untuk membenarkan adanya kausalitas teoritis melalui uji data empirik. Fokusnya adalah pada bagaimana aktivitasaktivitas premarket, issue date dan aftermarket berkaitan antara satu dengan lainnya, pada gilirannya berkaitan pula dengan longer-run investor returns.

5. Dengan diterbitkannya peraturan BAPEPAM No. IX.A.2 Baru, nampak adanya proses belajar dalam merespon peraturan baru tersebut. Proses belajar yang terus menerus ini perlu untuk perkembangan pasar modal Indonesia ke arah yang lebih baik. Beberapa hal yang perlu diperhatikan di dalam praktek adalah:

a) Peranan underwriter pada perioda premarket, karena menyangkut pengemasan harga yang strategik dengan mengacu pada hasil red herring.

b) Peranan underwriter pada perioda aftermarket, karena menyangkut performance saham. Price stabilization bukan satu-satunya alternatif pengendalian harga. Masih terdapat pilihan lain yang dapat digunakan secara strategis yaitu dengan menggunakan kombinasi aftermarket short covering, penalty bids dan penggunaan secara selektif overallotment options (Agganwal, 2000).

\section{DAFTAR PUSTAKA}

Allen, F., \& G.R. Faulhaber. 1989. Signaling By Underpricing in the IPO Market. Journal of Financial Economics, Vol. 23, pp. 303-323.

Angganwal, R. 2000. Stabilization Activities by Underwriters after Initial Public Offerings. The Journal of Finance, June, Vol. LV, No. 3, pp. 10751103. 
Arni Utamaningsih:PengaruhAktivitas Pasardan Reputasi-Underwriter ...

Ȧrbuckie, J.L. 1999. Amos 4.0.Programming Reíerence Guide. Chicago: SmallWaters Corporation.

Baron, D.P. 1982. A Model of the Demand for Investment Banking Advising and Distribution Services for New Issues. The Journal of Finance, September, Vol. XXXVII, No. 4, pp. 955-976.

Beatty, R.P., \& J.R. Ritter. 1986. Investment Banking, Reputation, and the Underpricing of Initial Public Offerings. Joumal of Financial Economics, Vọl. 15, pp. 213-232.

Benveniste, L.M., \& P.A. Spindt. 1989. How Investment Bankers Determine the Offer Price and Allocation of New Issues. Joumal of Financial Economics, Vol. 24, pp. 343-361.

Benveniste, L.M., W.Y. Busaba, \& W.J. Wilhelm, Jr. 1996. Price Stabilization as a Bonding Mechanism in New Equity Issues. Journal of Financial Economics, Vol. 42; pp. 223-255.

Bradley, D.J., \& B.D. Jordan. 2002. Partial Adjustment to Public Information and. IPO Underpricing. Journal of Financial And Quantitative Analysis, December, Vol. 37, No. 4, pp. 595-616.

Brav, A., \& P.A. Gompers. 1997. Myth or Reality? The Long-Run Underperformance of Initial Public Offerings: Evidence from Venture and Nonventure Capital-Backed Companies. The Journal of Finance, Vol. LII, No. 5, pp. 1791-1821.

Brennan, M.J. \& J. Franks. 1997. Underpricing, Ownership and Control in Initial Public Offerings of Equity Securities in the UK. Joumal of Finan- cial Economics, Vol. 45, pp. 391-413.

Carter, R., \& S. Manaster. 1990. Initial Public Offerings and Ùndenwriter Reputation. The Journal of Finance, September, Vol. XLV, No. 4, pp. .1045-1067.

Carter, R.B., F.H. Dark, A.K. Singh. 1998. Underwriter Reputation, Initial Returns, and the Long-Run Performance of IPO Stocks. The Journal of Finance, February, Vol. LIII, No. 1, pp. 285-311.

Ellis, K:, R. Michaely, \& M. O'Hara. 2000. When the Underwriter Is the Market Maker: An Examination of Trading in the IPO Aftermarket. The Journal of Finance, Vol. LV, No. 3, pp. 1039-1073.

Fishe, R.P.H. 2002. How Stock Flippers Affect IPO Pricing and Stabilization. Journal of Financial And Quantitative Analysis, June, Vol. 37, No. 2, pp. 319-340. 
. Grinblatt, M. \& C.Y. Hwang. 1989. Signalling and the Pricing of New issues. . The Journal of Finance, June, Vol. XLIV, No. 2, pp. 393-420.

.Hanafi, M. 2002. Efisiensi Emisi Saham Baru di Bursa Efek Jakarta 19891994. Bunga Rampai Kajian Teori Keuangan. Yogyakarta: BPFE, pp. 427-444.

Hanley, K.W. 1993. The Underpricing of Initial Public Offerings and the Partial Adjustment Phenomenon. Journal of Financial Economics, Vol. 34, pp. 231-250.

Hanley, K.W., A.A. Kumar, \& P.J. Seguin. 1993. Price Stabilization in the Market for New Issues. Journal of Financial Economics, Vol. 34, pp. 177-197.

Husnan, S. 2001. Dasar-dasar Teori Portofolio dan Analisis Sekuritas. Edisi Ketiga. Yogyakarta: Unit Penerbit dan Percetakan AMP YKPN.

Logue, D.E. 1973. On the Pricing of Unseasoned Equity Issues: 1965-1969. Journal of Financial and Quantitative Analysis, January, pp. 91-103.

Logue, D.E., \& J.R. Lindvall. 1974. The Behavior of Investment Bankers: An Econometric Investigation. The Journal of Finance, March, Vol. 29, pp. 203-215.

Logue, D.E., R.J. Rogalski, J.K. Seward, \& L.F. Johnson. 2002. What Is Special about the Roles of Underwriter Reputation and Market Activities in Initial Public Offerings?. Journal of Business, Vol. 75, No. 2, pp. 213-243.

Ritter, J.R. 1991, The Long-Run Performance of Initial Public Offerings. The Journal of Finance, March, Vol. XLVI, No.1, pp. 3-27.

Rock, K. 1986. Why New Issues Are Underpriced. Journal of Financial Economics, Vol. 15, pp. 187-212.

Tinic, S.M: 1988. Anatomy of Initial Public Offerings of Common Stock. The Journal of Finance, September, Vol. XLIII, No. 4, pp. 789-822.

Welch, I. 1989. Seasoned Offerings, Imitation Costs, and the Underpricing of Initial Public Offerings: The Journal of Finance, June, Vol. XLIV, No. 2, pp. 421-449. 